\title{
Philosophy and Ethics in Western Australian Secondary Schools
}

\author{
Stephan Millett \& Alan Tapper \\ Centre for Applied Ethics and Philosophy, Curtin University
}

\begin{abstract}
The introduction of Philosophy and Ethics to the Western Australian Certificate of Education courses in 2008 brought philosophy into the Western Australian secondary school curriculum for the first time. How philosophy came to be included is part of a larger story about the commitment and perseverance of a relatively small number of Australian educators and their belief in the value of introducing philosophical communities of inquiry into school classrooms through a revised pedagogy which could sit comfortably with an outcomes-based education system.
\end{abstract}

Keywords: curriculum framework, philosophy, ethics, outcomes, research

\section{A Brief History}

Philosophy is now included as one of 50 or so subject choices available to Western Australian students entering the final two years of high school. The course, part of the Western Australian Certificate of Education (WACE), enrolled its first students in 2008 and the first group of students sat the final year exams in 2009.

This article concerns the story of how this philosophy course came into being in Western Australian schools. But this is not a purely parochial story, as how Philosophy became part of the WACE, and how it came to have a particular pedagogical approach built in to the curriculum, is a chapter in an international story in which Australia and Australians have played a key role, in particular a group of people who advocate a particular pedagogy to help children do philosophy.

Advocacy for philosophy in schools in Australia goes back to about 1984, and begins with Laurance Splitter in Sydney. Splitter had been introduced to Philosophy for Children (P4C) by Matthew Lipman and Ann Sharp at Montclair State University in New Jersey. He then brought Lipman and Sharp to the University of Wollongong in July 1985 to run the first 'Level 2' workshop in Australia. A Level 2 workshop is an intensive week-long course for teachers and philosophers at which participants learn the effective teaching method pioneered by Lipman — a method grounded in Deweyan pragmatism and Vygotskyan psychology. Following the Wollongong workshop, Splitter and others set up the Australian Institute of Philosophy for Children (AIPC). This was a legally constituted national body which initially sold the Lipman texts (e.g. Harry Stottlemeier's discovery, Lipman, 1974) before handing that role over to Australian Council for Education Research, and was the forerunner for the current Federation of Australasian Philosophy in Schools Associations (FAPSA). 
In 1988 Splitter moved to the Australian Council for Education Research (ACER) in Melbourne and-thanks to the foresight and generosity of then ACER director Barry McGaw_ — set up a centre for philosophy for children. It is interesting to note McGaw's support of philosophy, which continues today in his role as Chair of the Board of the Australian Curriculum, Assessment and Reporting Authority, as the school-based movement and the Australasian Association of Philosophy combine to lobby for the inclusion of philosophy in the national curriculum. Almost all of the systems have now included philosophy as a secondary school subject. Queensland's programme was first, although it is more specialized than courses in other states; Victoria followed in 2001, South Australia in 2003, Tasmania in 2006 and Western Australia in 2008.1

\section{Western Australia}

The creation of the Western Australian Philosophy course was set against the background of the formation of the Western Australian Curriculum Council in 1997 and the development of the Curriculum Framework in 1998. The Council and the Framework brought dramatic changes to all schools in WA. The origin of these changes goes back to 1995 and the Review of School Curriculum Development Procedures and Processes in Western Australia, which identified a number of priorities, including the need for:

- a common curriculum direction that enabled curricula to be adapted to the advantage of students

- a seamless curriculum among the different levels of schooling

- greater involvement by non-government schools and the community in state-wide curriculum development processes.

The Curriculum Council was charged with developing a Curriculum Framework, a structure providing a mandatory common and seamless curriculum direction across all levels and all Western Australian schools.

Based on the comparative analysis of courses and the widespread support for the core shared values, Philosophy and Ethics was included as one of the possible courses in the Position Paper. However, a Religion course was not included and it became evident quite early in the next phase of the consultation process that while there was support for a Philosophy and Ethics course there was also a strong lobby for a Religion course. A focus group with a broad spectrum of views across religion and ethics debated the issues and it was clear that a Religion and Life course would be needed.

Stephan Millett's memory of that focus group session is of a religious lobby asserting that a Religion course was all that was needed as it could deal adequately with philosophical issues. Both courses were subsequently endorsed by the Council and both courses were included in Our youth, our future, the Council's review of post-compulsory education (Western Australia Curriculum Council, 2002).

The Curriculum Council became the overseeing body for the school system state-wide and it became mandatory for all schools, public and private, to adopt the policies developed by the Council. The 
Council's primary document was the Curriculum Framework, which introduced an 'outcomes-based' philosophy for schooling K-10, and embedded the 'core shared values' into the curriculum. The core shared values were themselves an 'ethics framework' for schooling, and were perhaps the first attempt in Australia to be explicit about values in a largely secular education system.

These core shared values were under four headings: (1) A pursuit of knowledge and a commitment to achievement of potential (2) Self-acceptance and respect of self (3) Respect and concern for others and their rights (4) Social and civic responsibility.

Under each of these headings was a set of more fine-grained descriptors, such as respecting individual differences, compassion and care; participation and citizenship.

Those educators familiar with P4C could see immediately that in taking part in a philosophical community of inquiry children would demonstrate each of the core shared values, so from the beginnings of the work on the new senior school course in Philosophy it was clear that it was compatible with this core component of the newly mandated framework.

However, after some years of an outcomes-based curriculum and new reporting processes related to it in the primary and middle school years, the Curriculum Council began detailed planning for a new upper school curriculum to replace the existing curriculum. All of the new subjects would be available to all students, whether they were applying for a Tertiary Entrance Ranking (TER) score, for entrance to technical and further education or other further education opportunities.

Each new course was to have a syllabus comprising outcomes, essential content and standards.

However, when the 'outcomes' reform process came to be implemented in the upper secondary level, a furore broke out that was to be heard across the country.

Four things happened at the same time.

- First, the course offerings for upper secondary were cut from 150 to 52 courses.

- Secondly, a number of new courses were included in the offerings, one of which was Philosophy and Ethics.

- Thirdly, compulsory education was extended to age 17 for the first time, and the newly designed courses had to be accessible to all students, not just those seeking university entrance.

- Fourthly, in the writing or rewriting of the 52 courses, an outcomes approach that had been accepted at lower levels was introduced at the top level.

It was this last change that was fiercely resisted by a section of the senior secondary teachers, perhaps mainly because they had to engage with outcomes in an exam environment, whereas previously, in lower school, teachers could to some degree ignore outcomes or pay lip service to them.

This controversy ran from 2004 until 2009, fuelled by local media with an interest in sensationalized reporting. 
Thus, the new Philosophy and Ethics course was born in a time of some turmoil.

Stephan Millett was awarded the tender to be the writer for the course. This involved working with a reference group with members from the universities and all sectors of secondary education. Fitting a philosophy course into a bed which was not a natural fit proved demanding. Forcing the course into a predetermined framework was not a problem unique to philosophy, but the goodwill and shared purpose of the reference group helped us to cut and stretch what we felt to be important to fit a mould that also served the more than 50 other courses. The writing of the Philosophy and Ethics course was largely completed in 2005.2

The course was trialled with action research in 2006, professional development followed from 2007, and the course itself was introduced formally in 2008. It was one of the few courses that kept to the timetable set out for it. In part that smooth introduction is explained by the strong representation on the reference group by members of the Association for Philosophy in Schools (APIS WA), who have been part of the Australian P4C movement and who have a shared understanding of the nature of the subject and of how it may be taught successfully to students with a range of intellectual abilities and cognitive maturity.

\section{Designing the Course}

The Philosophy and Ethics course was a completely new curriculum area for Western Australia. It, along with every other course, had to refer specifically to both what were called overarching outcomes and learning area outcomes which together made up the mandatory element of the Framework.3 The 52 new courses were introduced in three waves. Philosophy and Ethics was part of the second wave and synthesized outcomes from the learning areas of English, Arts, Science, Society and Environment, Media, and Technology and Enterprise. The course was intended to meet the needs of students: who wished to pursue the study of Philosophy and Ethics at tertiary level; who would continue studies in the vocational area; who intended to go straight into the workplace; and those who wished to develop skills for their own development and enjoyment.

In the design of the course, four features are noteworthy.

- The first is that from the outset philosophy was seen as quite distinct from religion.

- A number of people pointed out that since ethics is a branch of philosophy, it makes no sense to have it in the title. An explanation of the title can be found in the official Rationale. The title 'Philosophy and Ethics' gives ethics a prominent status, signifying that it has particular importance in this course. This status recognizes that every member of a society faces ethical issues. A philosophical approach helps people to reflect on, and better understand, difficult ethical issues.

- The third feature is that this course had to follow an 'outcomes-based' approach which meant it could not be designed simply as a body of content. It had to have three or four overarching outcomes.

- The fourth feature is that the reference group included people familiar with the techniques and philosophy underpinning P4C. In 1999, Stephan Millett became President of the WA 
Association for Philosophy in Schools and the association began running workshops for teachers on a regular basis, prompted initially by a group from the district high school in the small south-west town of Pemberton who had visited Buranda primary school in Brisbane.

Through subtle pressure from Felicity Haynes and Stephan Millett the reference group came to understand and then to embrace the Lipman method, the community of inquiry pedagogy, and the various modifications that have been made as P4C was 'Australianized'. This meant that we had a cohesive outlook and a shared understanding of how the course might best be taught. At no stage was there conflict about what we were trying to do and the Curriculum Council gave us full scope to follow our own professional inclinations.

\section{Bases of Pedagogy}

The pedagogy is informed by the democratic principles and philosophical pragmatism of John Dewey (1916/1966, 1910/1933, 1920/1957) and the psychology of learning of Lev Vygotsky (1978) in which ways of thinking experienced at the interpersonal level_ — in listening to the way others think — - are internalized to become a model for intrapersonal thinking. That is, each participant learns from dialogic interaction ways of developing effective self-talk, especially when they come to clarifying concepts and resolving problems. This tool, the philosophical community of inquiry, is deceptively simple but is very powerful, and routinely gives the teacher beautiful insights into the rich thinking that children are capable of when they talk and listen to each other in pursuit of conceptual clarity. The course Rationale, when it was finally approved, placed community of inquiry front and centre.

Through essential content, prescribed outcomes and partially prescribed pedagogy a course with six units was devised with the aim of developing in students thinking and analytical skills and moral discernment that may be applied to a range of practical situations in their personal, interpersonal and working lives.

\section{Essential Content}

The essential content of the course followed traditional lines, dividing into Metaphysics, Epistemology and Ethics, although these were expressed more colloquially in question form as:

- How do we know?

- What is real?

- How should we live?

These headings were elaborated in considerable detail. Content under 'How do we know?' was divided into: critical reasoning; methods of inquiry; imagination and interpretation; and analysing, clarifying and evaluating concepts. 'What is real?' comprised: scientific worldview; conceptions of ultimate reality; and persons. Content in 'How should we live?' was divided into: Self and others; communities and cultures; and governance. Some of these subdivisions were required by the Curriculum Framework.

\section{Outcomes}


Outcomes under the Curriculum Framework are 'statements of what students should know, understand, value and be able to do as a result of the syllabus content taught'.

The difficult task of designing suitable outcomes was resolved by settling on four outcomes, as follows:

- Outcome 1: Philosophical and ethical inquiry. Here students use investigative methods familiar to philosophers to think and argue philosophically. They participate in open philosophical communities of inquiry; explore philosophical and ethical concepts, ideas and ideals; and use critical reasoning methods to recognize, analyse, evaluate and develop arguments.

- Outcome 2: Philosophical and ethical perspectives. Students understand that there are philosophical and ethical approaches to making meaning.

- Outcome 3: Philosophy and ethics in human affairs. Students understand that philosophical and ethical thinking has a role in human affairs. In achieving this outcome, students understand that there are philosophical traditions; understand that there are different world views; and understand the influence of philosophical ideas on contemporary culture.

- Outcome 4: Applying and relating philosophical and ethical understandings.Students reflect on, evaluate and respond to a range of human issues by selecting from a repertoire of philosophical and ethical strategies.

An outcomes approach actually suits philosophy well, as philosophy can readily be thought of not so much as subject matter to be learned but as a set of skills to be acquired by practice. To quote the Rationale again: Philosophy and Ethics develops thinking skills and moral discernment that students apply to a range of practical situations in their personal, social and working lives. Such skills might be as evident in the mechanic who discusses with the owner why a machine is not working and what should be done as it would be in a doctor diagnosing illness and discussing treatment options with a patient.

One of the effects of an outcomes focus was to downplay the study of the history and classics of philosophy and to place the primary focus on reasoning skills (Outcome 1) and conceptual inquiry (Outcome 2) and on the ways in which these can be applied in a variety of contexts (Outcome 3).

\section{Measuring Outcomes}

Measuring outcomes in all upper secondary courses became a source of controversy that played out, primarily, in the local news media. The controversy was not without foundation, however, as assessment originally did not allow for external examinations and secondary teachers were concerned to ensure that marks from different schools remained comparable.

\section{Implementation}

As noted above, the course was introduced in a difficult period, and yet its introduction went off smoothly.4 The 'OBE (outcomes-based education) controversy' did nothing to delay the process. 
In 2009, in the second year of its life, about 450 secondary students in about ten schools5 were studying the Philosophy and Ethics course, up from 150 students in the previous year. In 2009 students sat the Tertiary Entrance Exam in Philosophy and Ethics for the first time.

The schools that have led the introduction include private and state schools whose students come from a range of socioeconomic backgrounds. However, to date, no Catholic schools have taken up the subject, and none has indicated any intention to do so. Catholic schools have chosen to support the religion course that they were instrumental in having approved.

An unexpected element of the story is that some of those leading the implementation process come from a background in the Dialogue Australasia Network (DAN), a non-denominational Christian organization.6 DAN was established in 2002 by Peter Vardy of Heythrop College, London, and describes itself as 'an exciting and important initiative arising from a commitment to develop Values, Philosophy \& Religious Studies with intellectual rigour and contemporary relevance in Australasian schools'.7 In its 'five-strand' approach DAN contends, for example, that students need to be made aware of 'the tension between belief in a wholly good and all powerful God and the undoubted reality of evil' and that they 'need to be given the opportunity to think through the consequences of this tension in an intellectual framework that takes the issues seriously, whilst also encouraging freedom of thought'.8 Taking this at face value, there is no obvious incompatibility between these approaches and that of the Lipman P4C tradition. However, the P4C tradition is more deeply embedded in the Western Australian Philosophy and Ethics course and that tradition will provide a framework for the subject in non-Christian schools.

\section{Resources and Teaching}

A perennial problem for wholly new courses, as this course is, is the need for appropriate teaching materials. However, a local publisher, Impact Publishing, offered the authors of this article the chance to write three textbooks tailored to the needs of the course. These were completed in 2007-20089 (Millett \& Tapper, 2007, 2008a, 2008b; see also Millett \& Tapper, 2011). The books are written with the aim of combining a 'community of inquiry' approach with an introduction to philosophical ideas, arguments and methods.

A more basic problem is 'human resources'. The long neglect of philosophy in schools means that very few current teachers have training in the subject area. Only a handful of teachers in the state have philosophy degrees. A few hundred have taken introductory Level One courses run by APIS, but many of these teachers are at primary school level. Thus, the teaching of philosophy and ethics will of necessity fall to those teachers who have studied a little philosophy and who have an enthusiasm for the subject sufficient to motivate them to go through a difficult learning process. If student demand for the course continues to grow, it will soon outstrip the supply of teachers. How to increase that supply remains an unsolved problem, but also presents an opportunity for education and philosophy schools in universities.

\section{The Wider Perspective}


Philosophy was once a central part of the tradition of English and Scottish schooling, on which Australian educational traditions are largely based. It was also once part of the Catholic tradition, which forms an important segment of Australian schooling.

Yet it has not been part of normal schooling for at least a century. The reintroduction of philosophy into Australian schools is a change worth viewing in a broad perspective.

Here, we canvass four aspects of the change: philosophy is becoming accepted in the curriculum; it offers a way of teaching values; it is relevant to academic and nonacademic levels of learning; and there is empirical evidence that it improves generic thinking skills.

First, there is the present status of philosophy in secondary schooling. Philosophy in Australian schools is 'in the process of coming in from the margins' (Millett, 2008) and has now been introduced into almost all secondary curricula, with the notable exception of New South Wales (NSW). This is summarized in Table 1.

Secondly, philosophy offers a way of teaching values. As we noted above, Western Australia is unusual in having a Curriculum Framework that incorporates an explicit set of 'core shared values' rather than something like the core values prescribed for NSW public schools, which refer to whole-ofschool behaviours rather than specifically to the curriculum.10 Typically, government schooling in Australia has been free, secular and compulsory, and in that formula 'secular' includes 'values neutral' in its implicit meaning. Philosophy, however, is a normative discipline. It involves the rational analysis of normative questions. This makes many of those from empirically-

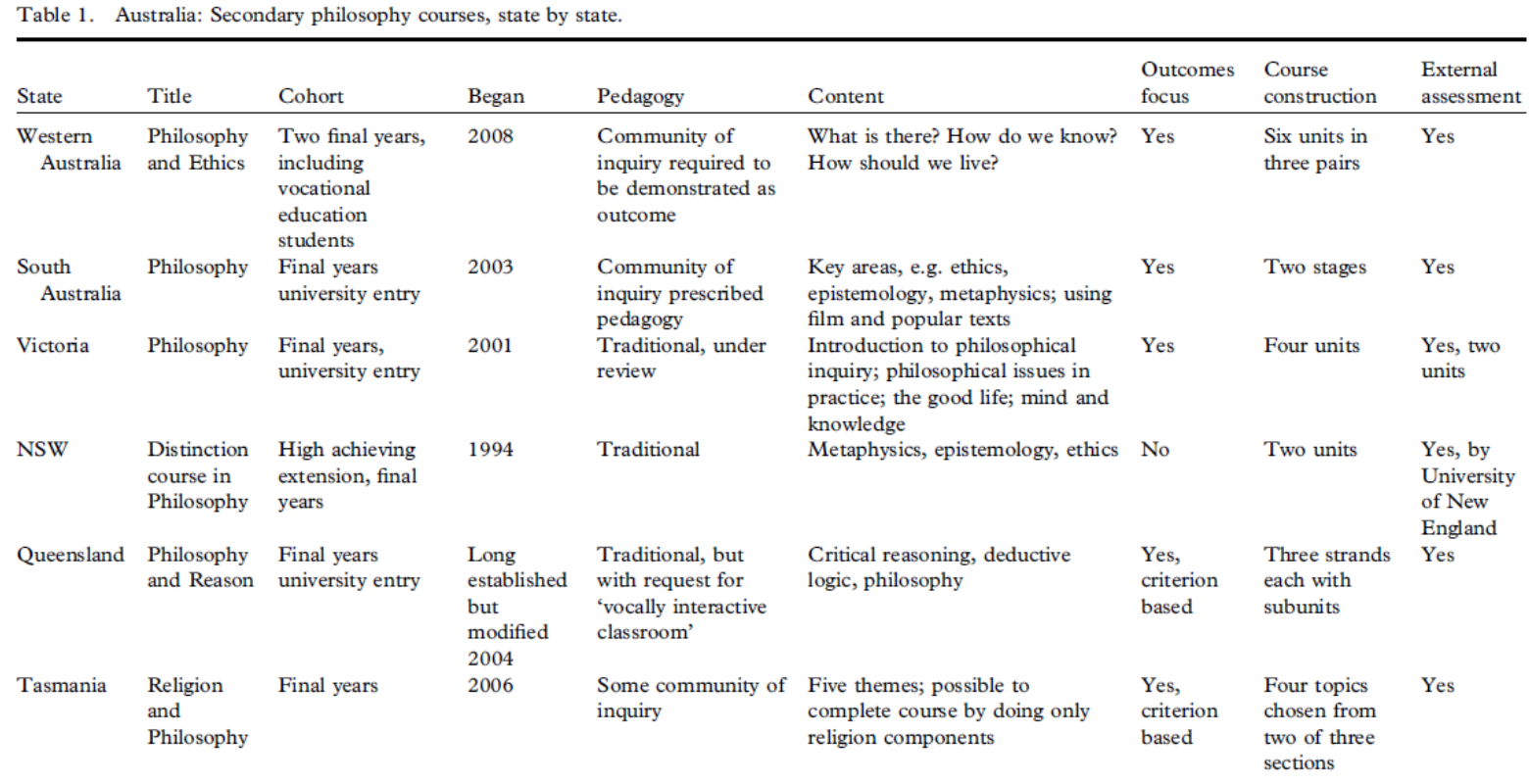

Table 1. Australia: Secondary philosophy courses, state by state.

minded disciplines distinctly uncomfortable, and there is a deeply embedded fact/ value dichotomy that underpins this uneasiness. Philosophers, however, debate whether there is any rational basis for this uneasiness. Some think that facts and values can be sharply distinguished; others think the opposite. When the values are ethical values, the tension between these viewpoints is even further increased. But these are matters that philosophy knows how to discuss, even if the discussion does 
not end in agreement. The rational basis of ethics has been a central topic since the time of Socrates and Plato.

In an empiricist culture such as ours, 'values' tend to be_—like a chronically misbehaving student- expelled from the curriculum. They are neither explicitly taught nor openly discussed. Yet this is incoherent, for three sorts of reason. One is that the school curriculum is already and undeniably value laden, at least as far as epistemic values are concerned. One cannot learn mathematics or history without learning to distinguish between false or worthless viewpoints and true and valuable viewpoints.

Secondly, the classroom is a value-laden environment, and this is so for a much broader range of values. It cannot function, for instance, unless some kinds of behaviour are promoted and others discouraged. Thirdly, since one aim of Australian schooling is to prepare students for life in a democratic society, the values that apply (or should apply) in the wider society can reasonably be included in the curriculum.

At the secondary level, this will include consideration of ways in which those values can be contested. This is already recognized in various ways in other disciplines, but philosophy makes these discussions explicit and central and focuses on the quality of the arguments, thus minimizing the risk of teachers imposing their selective visions on their students. One of the first rules of philosophy is that it is permissible, and even desirable, to disagree with the teacher, if one sees reason to do so. Of course, one can also disagree with one's fellow students.

Thirdly, philosophy is far from being a remote and academic subject fit only for high achievers intending to take an arts degree at university. Rather, philosophy in classes using the community of inquiry approach is a practical activity that helps students to understand, evaluate and engage with their world. It helps students to deal more effectively with disagreement and provides strategies to deal with issues that cannot be addressed simply by appeal to the senses or to some rule or law. Philosophy teaches transferable skills and makes a unique contribution to a student's understanding of his or her self. Philosophy aims to empower students to flourish in a world of increasing complexity of not just new problems, but new categories of problems.

Fourthly, strong empirical research now backs up strong claims about the value of philosophy in schools (Millett \& Tapper, 2011). The best research evidence comes from Clackmannanshire, Scotland, where Keith Topping and Steve Trickey studied the effects of collaborative philosophical inquiry on students in 18 primary schools (Trickey \& Topping, 2004, 2006, 2007; Topping \& Trickey, 2007a, 2007b):

- A whole population of children gained on average 6 standard points on a measure of cognitive abilities after 16 months of weekly enquiry (1 hour per week).

- Pupils and teachers perceived significant gains in communication, confidence, concentration, participation and social behaviour following 6 months of enquiry.

- Pupils doubled their occurrence of supporting their views with reasons over a 6 month period. 
- Teachers doubled their use of open-ended questions over a 6 month period.

- When pupils left primary school they did not have any further enquiry opportunities yet their improved cognitive abilities were still sustained 2 years into secondary school.

- Pupils increased their level of participation in classroom discussion by half as much again following 6 months of weekly enquiry. (Sutcliffe, in UNESCO, 2011, pp. 53-54) We should perhaps underline the point that 'communication, confidence, concentration, participation and social behaviour' all improved where students learned to participate in disciplined but democratic discussion.

Philosophy does not bring only intellectual gains. Another study, a meta-analysis of 18 studies of the cognitive effectiveness of the P4C approach, carried out by Garcia-Moriyon, Colom, Lora, and Rivas (2004), concluded that 'the implementation of P4C led to an improvement of students' reasoning skills of more than half a standard deviation'. This amounts to a gain of about seven IQ points. The researchers observed that 'The result is especially impressive if we note that P4C was never applied for more than one school year in all the studies reviewed' (Garcia-Moriyon et al., 2004, pp. 19, 21).

\section{Conclusion}

The Western Australian senior school curriculum is an example of how a proven pedagogy can be built into a curriculum in such a way that students, by working within this pedagogy, can achieve outcomes intended to make them good citizens capable of clear, considered and collaborative thinking.

Despite its effectiveness, philosophy in schools has suffered in part because it has not been adequately scoped and sequenced so that students are able to build their philosophical capacity in ways analogous to the ways their capacities in numeracy, literacy and scientific understanding are built across the whole of their schooling. With the weight of evidence showing significant and measurable improvements in cognitive and social elements for students who learn philosophical methods through collaborative classroom inquiry, it is time that philosophy became more fully enmeshed in school life and time that pre-service training for teachers included philosophical methods and appropriate pedagogy.

\section{Ethics Approval}

Interviews for this article were conducted with ethics approval from the Curtin University Human Research Ethics Committee, approval number RD-34-10.

Notes

1. For an earlier discussion of the state philosophy courses, see Millett (2006).

2. The course syllabus can be accessed at http://www.curriculum.wa.edu.au/internet/

Senior_Secondary/Courses/Philosophy_and_Ethics 3.

http://www.curriculum.wa.edu.au/internet/Years_K10/Curriculum_Framework (accessed November 2010).

4. Critics of OBE, many of whom joined the 'PLATO' lobby (people lobbying against teaching outcomes), commonly feared that declining educational standards would follow from the new curriculum approach. But it is 
not easy to argue that a subject as notoriously difficult as philosophy would have the effect of lowering school standards. In 2007, a few of the PLATO protagonists did in fact argue that philosophy was too difficult even for upper secondary school students. They took up this line of argument in ignorance of the 'philosophy in schools' movement. When the work of Dewey and Lipman was drawn to their attention, one or two tried to contend that this was not 'real philosophy', as measured by the yardsticks of Kant and Hegel. However, the argument died a natural death and had no impact on the implementation process. This argument took place on the forum of the PLATO website, http://www.platowa.com/, in 2007. The website is no longer active and the argument can no longer be accessed.

5. Australind Senior High School, Carey Baptist College, Christ Church Grammar School, Gilmore College, Hale School, Mt Lawley Senior High School, St Hilda's Anglican School for Girls, Perth College, Perth Modern School and Willetton Senior High School.

6. We have in mind Matthew Wills at Hale School (formerly DAN director) and Dominic Hodnett at Christ Church Grammar School. In 2007, with APIS member Leanne Rucks, Matthew Wills launched the 'Philosothon', now a rapidly growing annual interschool 'community of inquiry' event that is at once both competitive and cooperative. See the website, http://www.philosothon.org/

7. See DAN's website, http://www.dialogueaustralasia.org/ 8. See the 'five strands' at http://www.dialogueaustralasia.org/?page_id=23 9. The publisher's website is http://www.impactpublishing.com.au/catalogue.php?groupid=32 10. http://www.schools.nsw.edu.au/studentsupport/studentwellbeing/values/core/index.ph0070

\section{References}

Dewey, J. (1966). Democracy and education: An introduction to the philosophy of education. New York: Free Press. (Original work published 1916).

Dewey, J. (1933). How we think. A restatement of the relation of reflective thinking to the educative process (rev. ed.). Boston: D. C. Heath. (Original work published 1910).

Dewey, J. (1957). Reconstruction in philosophy. Boston: Beacon Press. (Original work published 1920).

Garcia-Moriyon, F. F., Colom, R., Lora, S., \& Rivas, M. V. (2004). Evaluation of Philosophy for Children: A program of learning thinking skills. Thinking: The Journal of Philosophy for Children, 17, 17-26.

Lipman, M. (1974). Harry Stottlemeier's discovery. New York: Columbia University Press.

Millett, S. (2006). Philosophy in upper secondary school: An example from Western Australia.

In H. W. Kam (Ed.), Philosophy in schools: Developing a community of inquiry. Report on the proceedings of the conference (pp. 87-99). Singapore: Singapore Teachers' Union.

Millett, S. (2008). Coming in from the margins: Teaching philosophy in Australian schools. Thinking, 19.

Millett, S., \& Tapper, A. (2007). Philosophy and ethics. A resource for units 2A and 2B. Perth: Impact Publishing.

Millett, S., \& Tapper, A. (2008a). Philosophy and ethics. A resource for units 1A and 1B. Perth: Impact Publishing.

Millett, S., \& Tapper, A. (2008b). Philosophy and ethics. A resource for units 3A and 3B. Perth: Impact Publishing.

Millett, S., \& Tapper, A. (2011). Benefits of collaborative philosophical inquiry in schools.

Sutcliffe, R. (2011). In UNESCO High level regional meeting on the teaching of philosophy, February 14-16, Milan (pp. 53-54). Retrieved from www.unesco.org 
Topping, K. J., \& Trickey, S. (2007a). Collaborative philosophical enquiry for school children: Cognitive effects at 10-12 years. British Psychological Society.

Topping, K. J., \& Trickey, S. (2007b). Collaborative philosophical state inquiry for schoolchildren: Cognitive gains at 2-year follow-up. British Journal of Educational Psychology, 77, 787-796.

Trickey, S., \& Topping, K. J. (2004). Philosophy for children: A systematic review. Research Papers in Education, 19, 363-378.

Trickey, S., \& Topping, K. J. (2006). Collaborative philosophical inquiry for school children: Socio-emotional effects at 11 to 12 years. School Psychology International, 27, 599-614.

Trickey, S., \& Topping, K. J. (2007). Collaborative philosophical enquiry for school children: Cognitive effects at 10-12 years. British Journal of Educational Psychology, 77, 271-288.

Vygotsky, L. S. (1978). Mind in society: The development of higher psychological processes.

M. Cole, V. John-Steiner, S. Scribner \& E. Souberman (Eds.). Cambridge, MA: Harvard University Press.

Western Australia Curriculum Council. (2002). Our youth, our future: Post-compulsory education review:

Summary of the directions endorsed by the Western Australian government/Curriculum Council. Osborne Park, WA: Curriculum Council. 